\title{
Internet, Participation in International Trade and Tax Revenue Instability
}

\author{
Sèna Kimm GNANGNON ${ }^{1}$
}

Manuscript date: October 2020

\begin{abstract}
This paper investigates the effect of the Internet on tax revenue instability, notably through the international trade channel. It has used a sample of 142 countries over the period 1995-2017, and relied primarily on the two-step system Generalized Methods of Moments (GMM) estimators (but also incidentally on the Error Component Two-Stage Least Squares estimator). Tax revenue instability is primarily measured by the instability of non-resource tax revenue, but also by the instability of total tax revenue (for robustness check). The findings indicate that the Internet exerts a negative effect on tax revenue instability. Interestingly, this effect genuinely translates through the international trade channel, regardless of the measure of tax revenue instability considered. Countries enjoy a higher negative effect of the Internet on tax revenue instability as they enjoy a greater participation in international trade. These findings, therefore, add to the potential benefits of the Internet adoption (e.g., strengthening countries' participation in international trade, enhance their tax revenue performance and promote tax reform, including in developing countries) by showing that it could also help to stabilize tax revenue, particularly through the degree of countries' participation in international trade.
\end{abstract}

Keywords: Internet use; Participation in international trade; Tax revenue instability. Jel Classification : L86; F13; F14; H20.

\section{DISCLAIMER}

This is a working paper, which represents the personal opinions of individual staff members and is not meant to represent the position or opinions of the WTO or its Members, nor the official position of any staff members. Any errors or omissions are the fault of the author. The author declares no competing interests.

${ }^{1}$ World Trade Organization (WTO). E-mail for correspondence: kgnangnon@yahoo.fr 


\section{Introduction}

Digital technologies, underpinned by the widespread use of the Information Communication and Technology (ITC) tools - notably the Internet - are profoundly changing people's life around the world, affecting all activities in the society, and exerting strong impacts on countries' economic, financial, social and environmentally sustainable paths (ECLAC, 2016; OECD, 2016). Meanwhile, Kenny (2003) has noted that past "information revolutions" have had a limited impact on less-developed countries, probably because these countries were ill-prepared (due to the absence of the appropriate physical and human capital, as well as institutions) to take advantage of the digital economy.

Recent years have witnessed several empirical studies on the macroeconomic effects of the Internet penetration, including inter alia, on international trade (e.g., Freund and Weinhold, 2002, 2004; Clarke and Wallsten, 2006; Vemuri and Siddiqi, 2009; Lin, 2015; Gnangnon and Iyer, 2018) and public revenue ${ }^{2}$ (Gnangnon and Brun, 2018; Gnangnon and Brun, 2019a). In the literature survey on the effects of the Internet openness, the Organization for Economic Cooperation and Development (OECD, 2016, p35) has noted concerning specifically the international trade effects of the Internet that, there seems to be a consensus on the positive effect of the Internet openness on international trade, notably through its trade costs reduction effects. On the other hand, while the literature has started paying attention to the public finance effects of the Internet, the focus of the very few existing empirical studies (Gnangnon and Brun, 2018; Gnangnon and Brun, 2019a) has been on public revenue, including tax revenue. Gnangnon and Brun (2018) have shown that a lower gap between a country's Internet penetration and the world's average Internet penetration influences positively its non-resource tax revenue. Gnangnon and Brun (2019a) have uncovered that greater access to the Internet alters the structure of public revenue, including by reducing countries' dependence on resource revenue at the benefit of non-resource revenue. However, we are not aware of any study on the effect of the Internet on tax revenue instability.

The present paper aims to fill this gap in the literature by exploring empirically the effect of the Internet on tax revenue instability through the international trade channel. The rationale for examining the effect of the Internet on tax revenue instability two-fold. First, the instability of tax revenue is a major source of concern for policymakers in all countries in the world, notably in

2 Other studies have focused for example on economic growth (e.g., Choi and Yi , 2009; Maurseth, 2018; Salahuddin and Alam, 2015; Salahuddin and Gow, 2016); foreign direct investment (FDI) inflows (e.g., Choi, 2003; Ko, 2007), inflation (e.g., Meijers, 2006; Yi and Choi, 2005), labor productivity (e.g., Najarzadeh et al. 2014), the size of the shadow economy (Elgin, 2013); corruption (e.g., Elbahnasawy, 2014; Kanyam et al., 2017; Lio et al., 2011), CO2 emissions (e.g., Salahuddin et al., 2016); insurance growth (e.g., Benlagha and Hemrit, 2020); employment (e.g., Hjort and Poulsen, 2019); tax reform (Gnangnon, 2020a) and economic sophistication (e.g., Lapatinas, 2019). 
developing countries: greater instability of tax revenue induces a higher instability in public expenditure (e.g., Lim, 1983; Bleaney et al., 1995; Ebeke and Ehrhart, 2012) as well as higher instability of public investment and government consumption, and lower level of public investment (Ebeke and Ehrhart, 2012). In turn, these could significantly hurt economic growth (e.g. Afonso and Furceri, 2010; Gong and Zou, 2002). Second, in light of the rise of their integration into the world trade and financial markets, developing countries have experienced a higher proneness to external shocks (e.g., Álvarez et al., 2018; Guillaumont, 2009; Essers, 2013), which are found to be more persistent than those affecting developed countries (e.g., Aguiar and Gopinath, 2007). Additionally, the frequency of these shocks is far higher than in advanced economies (e.g., Barrot et al. 2018; Cariolle et al. 2016; Dabla-Norris and Gündüz, 2014). These shocks impinge on the dynamics of fiscal policy (e.g., Narayan and Lu, 2011; Solimano and Calderon, 2017), and could particularly enhance tax revenue instability (e.g., Dawkins and Whalley, 1997; von Haldenwang et al., 2013). As the Internet influences international trade, and hence countries' integration into the world trade markets, it is likely that it also influences tax revenue instability through the international trade channel.

Against this backdrop, the current paper addresses the issue as to whether the Internet affects tax revenue instability through the international trade channel (i.e., as countries better integrate into the world trade market) by relying on a panel dataset of 142 countries over the period 1995-2017. The findings based primarily on the two-step system Generalized Methods of Moments (GMM) estimators - and incidentally on the Error Component Two-Stage Least Squares estimator - indicate that the Internet helps reduce tax revenue instability, particularly in countries that experience a greater participation in international trade.

The rest of the paper is organized around four sections. Section 2 presents a theoretical discussion on how the Internet can affect tax revenue instability through the international trade channel. Section 3 discusses the empirical strategy, and Section 4 interprets the empirical outcomes. Section 5 concludes.

\section{Theoretical motivation: effect of the Internet on tax revenue instability through the international trade channel}

This section discusses the effect of the Internet on tax revenue instability through the international trade channel, notably through countries' participation in international trade. To that end, it first provides a brief literature review on the effect of the Internet on international trade, and then discusses how international trade could affect tax revenue instability. In turn, this 
discussion helps consider the effect of the Internet on tax revenue instability through the international trade channel.

There is a growing literature on the effect of the Internet on international trade. The essential role of trade costs in reducing trade flows has been well documented in the literature ${ }^{3}$. The adverse effect of information cost (i.e., acting as informal barrier) on international trade has been emphasized by studies such as Roberts and Tybout (1997), Belderbos and Sleuwaegen (1998), Petropoulou (2011), Rauch (1996), Rauch and Casella (2003), Rauch and Trindade (2002) and Tang (2006). Greater access to the Internet ${ }^{4}$ can allow trading firms to enjoy a large access to knowledge information (on potential markets, clients, suppliers and competitors) and ideas (e.g., Arthur, 2007; Paunov and Rollo, 2016). As a result, the Internet use could help reduce information costs, and hence promote international trade for existing businesses, by connecting suppliers with existing consumers located beyond the borders of the supplier's home country (or countries), as well as by improving logistics control. This effect is particularly strong in the context of global value chains where the Internet openness and digitization replace some physical trade with online trade, and facilitate the transactions and delivery of products, services, and payments faster and more efficiently (OECD, 2016). Specially, the Internet openness can benefit to smaller firms' participation in international trade (e.g., Acs et al., 1994; OECD, 2016; Nicholson and Noonan, 2014) and allow informal firms with limited resources (that prevent them from benefitting more from international trade) to overcome these resources obstacles and build knowledge networks (e.g., Jensen, 2007). Furthermore, greater access to the Internet can increase the number of innovating firms, and hence promote inclusive innovation in emerging and developing countries (e.g., Paunov, 2013; OECD, 2015).

On the empirical front, Freund and Weinhold (2002) have reported a strong positive impact of the Internet on trade in services growth. Similarly, Freund and Weinhold (2004) have relied on a model with imperfect competition and sunk costs of entry into a foreign market, and obtained empirically that the Internet contributes to promoting export growth notably by reducing marketspecific fixed costs, and enhance competition. Building on the work by Freund and Weinhold (2004), Lin (2015) has obtained empirically that an increase in the Internet users affects positively international trade. Clarke and Wallsten (2006) have found that a greater use of the Internet enhances developing countries' export performance, but not that of developed countries: greater

\footnotetext{
${ }^{3}$ Studies on this matter include for example Baldwin (1988); Bankolea et al. (2015); Behar and Venables (2011); Fink et al. (2005); Freund (2000); Gervais and Jensen (2019); Limão and Venables (2001); Meltiz (2003); Hummels (2007); Roberts and Tybout (1997); Tang (2006) and Visser (2019).

${ }^{4}$ The benefits and challenges of the Internet use (and the Internet openness) are documented in OECD (2016) and Paunov and Rollo (2016).
} 
access to the Internet in developing countries allows them to increase their exports to developed countries. According to Clarke (2008), a greater access to the Internet significantly helps enterprises in low and middle-income economies in Eastern Europe and Central Asia to enjoy higher exports. Evidence of a positive effect of the Internet on international trade has also been reported by Vemuri and Siddiqi (2009) and Meijers (2012). However, the latter has uncovered that the Internet exerts a higher positive effect in non-high-income countries than in high income countries. Portugal-Perez and Wilson (2012) have reported that ICT tools exert a positive effect on exports, and the magnitude of this effect increases as countries become richer. Choi (2010) has found empirically that the number of internet users influences positively trade in services. Along the same lines, Tay (2015) has found a strong and positive effect of the Internet on trade in educational services. In line with previously highlighted studies, Osnago and Tan (2016) have observed that the Internet adoption influences positively international trade, although bilateral exports are more affected when Internet adoption increases in the exporting country than the importing country. Abeliansky and Hilbert (2017) have investigated the differential effects of telecommunication quantity (data subscriptions per capita) and quality (bandwidth data speed per subscription) of fixed and mobile telephony and internet services on countries' bilateral goods exports. Their results have revealed that it is the bandwidth speed of phones and internet that matter most for developing countries, while for developed ones, the number of phones and internet subscriptions are much relevant. Gnangnon and Iyer (2018) have reported empirical evidence that countries that narrow the gap between their Internet penetration rate and the world average Internet penetration rate enjoy greater integration into the world trade in commercial services market. Visser (2019) have obtained a positive association between the Internet penetration and the extensive and intensive margins of differentiated exports. The findings indicate, additionally, that Internet penetration can increase exports at the extensive margins between low-income countries and high-income countries, but not within each of these groups. Ding (2020) has analysed the impact of the Internet on international trade from the perspective of asymmetric information, the latter being considered as the root cause of a bullwhip effect. The analysis indicates that the rapid development of the Internet provides countries with a new means for controlling the bullwhip effect of asymmetric information, and therefore, helps enhance the efficiency of the supply chain.

Now, as it appears clearly from the above-literature review - as well as from fact-based statistics (see for example, OECD, 2016) - that the Internet adoption promotes international trade, the effect of the Internet on tax revenue instability would ultimately depend on how participation in international trade affects tax revenue instability. 
The tax revenue instability effect of countries' participation in international trade, including through for example greater trade openness, has been discussed recently in Gnangnon and Brun (2019b). On the one hand, trade openness can induce greater instability of tax revenue by enhancing countries' vulnerability to idiosyncratic shocks. The enhancement of countries' vulnerability to external shocks could take place through a variety of avenues (see Montalbano, 2011). These include, for example, the apparent asymmetry between the process of increasing specialization and the presence of random and undiversifiable shocks in the export markets of open economies (e.g., Koren and Tenreyro, 2007); commodity prices volatility, notably in developing countries (e.g., Malik and Temple, 2009; McGregor, 2017; von Arnim et al., 2018); the fact that the existing local market structures and the traditional coping mechanisms are not well appropriate to address shocks prevailing in open markets (e.g., Dercon, 2001); the boom-bust cycles of investment supported by self-fulfilling expectations, where 'optimistic' expectations, 'good' terms-of-trade and investment boom can alternate with 'pessimistic' expectations, 'bad' terms-of-trade and investment bust - these may explain the excessive terms of trade volatility in developing countries compared to developed ones (Razin et al., 2003); and the possible high risk of mis-management policy in countries with weak political institutions that open to trade (e.g., Rodrik, 1999; Acemoglu et al., 2003). On another note, greater trade openness could be associated with the volatility of aggregate outcome variables, such as aggregate income, consumption, employment, salaries, and prices (e.g., Ahmed and Suardi, 2009; di Giovanni and Levchenko, 2009; Haddad et al., 2011, 2013; Kim et al., 2016; Raddatz, 2007). In turn, the volatility of aggregate outcome variables could translate into the instability of the tax base, and induce greater tax revenue instability. Authors such as Cavallo and Frankel (2008) have emphasized that trade openness can contribute to triggering "sudden stops": this could render instable the tax base, and hence enhance tax revenue instability. Others such as Ozkan and Unsal (2012) have demonstrated empirically the role of trade openness in strengthening the severity of financial crises in emerging markets. Against this background, we can argue that if greater participation in international trade is associated with tax revenue instability, then greater use of the Internet (which promotes participation in international trade) can enhance tax revenue instability (Hypothesis 1).

On the other hand, greater participation in international trade (e.g., through higher trade openness) could help reduce countries' vulnerability to idiosyncratic sectoral shocks through production and export diversification (e.g., Acemoglu and Zilibotti 1997; Haddad et al. 2011). As a result, countries would experience lesser fluctuations of the tax base, and enjoy greater stability of tax revenue. According to Haddad et al. (2011), trade openness can allow countries (i.e., trading firms in these countries) to share international risks, thanks to the possibility of a higher integration 
into a broader range of global value chains, through implicit and explicit insurance schemes such as joint ventures, international lending, production diversification and formal insurance contracts. Barthélémy et al. (2020) have shown that trade openness can contribute to worldwide economic recoveries after a financial crisis. In this context, trade openness can help dampen tax revenue instability. Summing up, in the scenarios where greater trade openness would be associated with greater stability of tax revenue, one could expect a greater Internet penetration to be associated with lower tax revenue instability as countries increase their participation in international trade (Hypothesis 2). Finally, trade openness may exert no significant on macroeconomic volatility (e.g., Calderon et al., 2005 and Kose and Yi, 2006), and hence on tax revenue instability. In such a case, the Internet use would not exert a significant effect on tax revenue instability in countries that promote their participation in international trade (Hypothesis 3).

Overall, the discussion laid out above does not allow concluding on the precise direction in which the Internet could influence tax revenue instability, as countries experience a greater participation in international trade (it is not clear which hypothesis among the three hypotheses set out above would dominate the others). The issue of the effect of the Internet on tax revenue instability through the international trade channel is therefore empirical.

\section{Empirical strategy}

This section first lays down the model specification that allows addressing the issue at hand. Second, it discusses the econometric method to carry out the empirical analysis.

\subsection{Model specification}

In contrast with the voluminous literature on the determinants of public revenue, including in developing countries, very few studies have investigated the determinants of tax revenue instability (e.g., Lim, 1983; Bleaney et al., 1995; Ebeke and Ehrhart, 2012; Ebeke, 2014; Gnangnon, 2020b; Gnangnon and Brun, 2019b). Building on these few works, we postulate a dynamic model specification where the dependent variable (i.e., tax revenue instability) is regressed on the indicator of the Internet penetration, and on a set of control variables. The latter include the real per capita income, denoted "GDPC", which acts as a proxy for countries' level of economic development; the volatility of economic growth ("GRVOL"); the volatility of development aid ("ODAVOL"); the share (\%) of total natural resources rents in GDP (denoted "RENT"), which acts as a proxy for countries' dependence on natural resources; the volatility of inflation rate ("INFLVOL"), and a measure of terms of trade instability ("TERMSVOL"). As the variable measuring countries' 
participation in international trade represents the channel through which the Internet is expected to influence tax revenue instability, it is not included in the baseline model specification, and would be included latter in the empirical analysis.

We postulate the following model specification:

$$
\begin{aligned}
& \log (\text { TAXINST })_{i t}=\alpha_{0}+\alpha_{1} \log (\text { TAXINST })_{i t-1}+\alpha_{2} \text { INTERNET }_{i t}+\alpha_{3} \log (\mathrm{GDPC})_{i t}+ \\
& \alpha_{4} \log (\mathrm{GRVOL})_{i t}+\alpha_{5} \log (\mathrm{ODAVOL})_{i t}+\alpha_{6} \mathrm{RENT}_{i t}+\alpha_{7} \log (\mathrm{INFLVOL})_{i t}+ \\
& \alpha_{8} \log (\mathrm{TERMSVOL})_{i t}+\gamma_{t}+\mu_{i}+\omega_{i t}
\end{aligned}
$$

This model has been estimated using an unbalanced panel dataset comprising 142 countries $^{5}$ (the subscript $i$ in equation (1) refers to a given country) over the period 1996-2017. The key variable of interest in the analysis is "INTERNET". It represents the Internet penetration (or level of the Internet use), and is measured by the number of individuals using the Internet, in percentage of the total population. All variables contained in model (1) are described in Appendix 1. Drawing for example from Gnangnon and Brun (2019b), and in particular from Gnangnon (2020b), the indicator of tax revenue instability has been computed over non-overlapping sub-periods of 3year. These sub-periods include 1995-1997; 1998-2000; 2001-2003; 2004-2006; 2007-2009; 20102013; and 2014-2017 (the latter covers a 4 -year sub-period rather than a 3-year sub-period). The subscript $t$ in equation (1) refers to each of these seven sub-periods. Thus, the indicator capturing the instability of tax revenue has been computed as the standard deviation of annual growth rate of tax revenue (\% GDP) over non-overlapping sub-periods of 3-year. Tax revenue has been primarily measured by the share of non-resource tax revenue (excluding grants and social contributions) in GDP. Non-resource tax revenue represents the difference between total tax revenue (\% GDP) (excluding social contributions) and tax revenue collected on natural resources. The use of non-resource tax revenue ( $\%$ GDP) as the main indicator of tax revenue is dictated by the fact that the exclusion of tax revenue on natural resources from total tax revenue helps ensure homogeneity in the tax revenue variable across countries in the full sample (e.g., Brun et al., 2015). For robustness check analysis, we have also computed the instability of tax revenue using the ratio of total tax revenue (excluding grants and excluding social contributions) to GDP. Summing up, the dependent variable "TAXINST" is primarily measured by the instability of non-resource tax revenue, and for robustness check, it is measured by the instability in tax revenue. $\alpha_{0}$ to $\alpha_{8}$ stand

${ }^{5}$ The analysis has excluded developed countries, qualified as "old industrialized countries" (e.g., Australia, Austria, Canada, Denmark, France..etc). As development aid volatility is a control variable in the analysis, we have selected -for the analysis countries that had been recipients of development aid over the period 1997-2017, and for which data on other control variables is available. 
for parameters to be estimated. $\gamma_{t}$ are time dummies that represent global shocks affecting together all countries' tax revenue and resulting in tax revenue instability. $\mu_{i}$ are countries' fixed effects; $\omega_{i t}$ represent a well-behaving error term.

The variables "GRVOL", "ODAVOL", "INFLVOL" and "TERMSVOL" have been computed over non-overlapping sub-periods of 3-year (see Appendix 1 for more details on the computation of these variables). The natural logarithm has been applied to all volatility variables so as to limit their high skewness. For the sake of consistency, averages of the other variables, including "INTERNET", "GDPC" and "RENT" have been computed over the aforementioned seven non-overlapping sub-periods of 3-year. Note that the natural logarithm has also been applied to the variable "GDPC" so as to reduce its high skewness. We have presented in Appendix 2 the descriptive statistics on all variables of model (1), and in Appendix 3, the list of countries utilized in the empirical analysis. Finally, it is worth noting that following many previous studies cited above (e.g., Ebeke and Ehrhart, 2012; Ebeke, 2014; Gnangnon, 2020; Gnangnon and Brun, 2019b), the one-period lag of the dependent variable has been introduced as a regressor. This helps take into account the potential existence of state dependence path in (i.e., the persistence over time of) tax revenue instability, and therefore helps avoid the bias that could be introduced by the omission of this variable in the model.

Using non-overlapping sub-periods of 3-year data, we present in Figure 1, a simple correlation pattern between the variable "INTERNET" and each of the two indicators of "TAXINST" (i.e., where the natural logarithm has not been applied/and has been applied to the indicator "TAXINST"). The patterns between "INTERNET" and the tax revenue instability indicators (without the natural logarithm) do not show a clear-cut direction of the correlation, but indicate the presence of outliers. Rather, in the graphs where the natural logarithm has been applied to the tax revenue instability indicators, there is really no outlier problems, and the correlation pattern between the variable "INTERNET" and each of the tax revenue instability indicators tends to be negative. These justify why the natural logarithm has been applied to the variable "TAXINST" (the same logic applies to other volatility variables in model (1)).

In terms of the theoretical effects of control variables on tax revenue instability, we expect that in light of their stronger human resources and institutional capacity, countries with a higher real per capita income are likely to better cope with the adverse effects of shocks on their economies (compared to relatively less advanced countries), and hence mitigate the intensity of tax revenue instability (see also Gnangnon and Brun, 2019b). Thus, we can expect a rise in the real per capita income to be associated with lower degree of tax revenue instability. 
Following for example Gnangnon and Brun (2019b), we postulate that greater economic growth volatility, higher inflation volatility, and a rise in terms of trade instability would translate in higher fluctuations of the tax base elements, and result in higher tax revenue instability. The effect of development aid volatility on tax revenue instability has been discussed in Gnangnon and Brun (2019b): we argue here that development aid volatility could enhance the instability of tax revenue, in particular as development aid plays an essential role in strengthening the capacities of tax and customs administration to mobilize tax revenue (Brun et al., 2011), and in enhancing tax compliance (e.g., Morrissey, 2015). Likewise, if development aid flows contribute to dampening the positive effects of shocks on output (e.g., Chauvet and Guillaumont, 2009), then one could expect the volatility of these capital flows to induce lower output volatility in the event of shocks, and hence lower instability of tax revenue. All in all, the direction of the effect of development aid volatility on tax revenue instability is a priori undetermined. Finally, the variable "RENT" has been introduced in model (1) to capture the extent to which natural resource dependence could matter for tax revenue instability. In fact, economies that are highly dependent on natural resources are less diversified, and prone to the vagaries of the world market (e.g., Lashitew et al., 2020), which could induce high economic volatility (e.g., Joya, 2015) and hence, greater tax revenue instability.

\subsection{Econometric approach}

To obtain reliable results from the estimation of model (1) (as well as its different variants described below), we need to choose an appropriate econometric estimator. One feature of this model is that a number of its variables could be suspected to be endogenous, due in particular to the bi-directional causality between some regressors and the tax revenue instability variables. These include the key variable of interest, that is, the Internet penetration rate, the volatility of development aid, and the share of natural resources in GDP. The rationale for the possible reverse causality of each of these variables is as follows. Concerning the Internet penetration variable, policymakers might develop the Internet-related infrastructure, and promote the usage of the Internet if the latter contributes to dampening tax revenue instability. On the other hand, tax revenue instability might deprive governments from the financial means necessary to cope with the adverse effects of shocks that hit the economy and translate into greater economic growth volatility. In the meantime, while development aid volatility might affect tax revenue volatility, donor-countries might be willing to reduce the level of volatility of development aid flows so as to help recipient-countries ensure a stability of their tax revenue. Finally, greater tax revenue instability may limit countries' capacity to rely on (stable and predictable) financial resources that 
would help invest in the diversification of their economies, and hence reduce the dependence of their economies on natural resources.

In light of these developments, we first estimate a static specification of model (1) (i.e., model (1) from which we remove the lagged dependent variable) using two standard econometric estimators, including the within fixed effects (denoted "FE") estimator, the Feasible Generalized Least Squares (denoted "FGLS") estimator. In the static specification of model (1), we have used a one-period lag of each of the three endogeneity variables ("INTERNET", "GRVOL", and "RENT") so as to mitigate their potential endogeneity. The results of these estimations are presented in columns [1] and [2] of Table 1.

Second, we estimate the static specification of model (1) - where the variables "GRVOL", "ODAVOL", and "RENT" are considered with a one-period lag - using the Error Component two-stage least squares (denoted "EC2SLS"), which provides for an instrumental variable approach to address the endogeneity of the Internet penetration. We would have used the fixed effects2SLS approach, in lieu of/or as a complement to the EC2SLS approach. However, the fixed effects-based 2SLS estimator (which disregards between-country variations) has led to a considerable efficiency loss in the estimates (results could be obtained upon request) because many variables in the model display a dominance of the between-country variation over the withincountry variation, and therefore, renders irrelevant a fixed effects approach. The EC2SLS estimator, which has been proposed by Baltagi (1981) is a random effects estimator with a matrix weighted average of the between 2SLS and the within fixed effects 2SLS approaches. According to Baltagi and Liu (2009), this estimator is more efficient in small samples and outperforms the Generalized Two-Stage Least Square estimator. In the estimation based on the EC2SLS approach, we have used two variables as instruments of the variable "INTERNET" (see also Gnangnon, 2020a). The first variable is the share of the population that has access to electricity, denoted "SHPOPELEC": it represents an indicator of the power supply, and reflects the costs of acquiring and using technology. Yartey (2008) has argued that a rise in electricity consumption influences positively the Internet penetration. In support of this, Gnangnon (2019) has uncovered that the share of the population with access to electricity has exerted a positive effect on the Internet penetration. The second variable, denoted "SHURBPOP", is the share of the population living in urban areas. According to Forman et al. (2002), the share of the population living in urban areas could exert a positive or negative influence on the Internet penetration. On the one hand, a rise in urban population could lead to a rise in the demand for information-intensive products and services. On the other hand, the need for ICT to compensate for distance-related communication might fall as the degree of urbanization rises. In the present analysis, we have found that both 
"SHPOPELEC" and "SHURBPOP" are positively and significantly (at the 1\% level) associated with the Internet penetration, irrespective of whether the regression of the Internet penetration variable on these two instruments is performed using the within fixed effects or the random effects estimator. The outcomes arising from the estimation of the static model (1) using the EC2SLS approach are displayed in column [3] of Table 1.

Relying on the static specification of model (1) may suffer from the endogeneity associated with the absence of the one-period lag of the dependent variable as a regressor (so as to capture the state dependence nature of the tax revenue instability indicator) in the model. Therefore, we pursue the analysis by using the Generalized Methods of Moments (GMM) approach, notably the two-step system GMM estimator to estimate the dynamic specification of model (1), that is, model (1) as it stands (see also Ebeke and Ehrhart, 2012; Ebeke, 2014; Gnangnon, 2020; Gnangnon and Brun, 2019b who have used this estimator in their analysis). The two-step system GMM estimator, proposed by Blundell and Bond (1998), is particularly suitable for dynamic panel dataset that feature a large number of individuals (here, countries) relative to the time period (e.g., Roodman, 2006) and where variables exhibit a strong persistence over time. Its use involves the estimation of a system of equations that includes an equation in differences, and an equation in levels, where lagged first differences being used as instruments for the levels equation, and lagged levels being used as instruments for the first-difference equation. This estimator has the potential of dealing with the endogeneity problem arising from the correlation between the one-period lag of the dependent variable and countries' specific effects, as well as the endogeneity (here, reverse causality) of the variables mentioned above. The two-step system GMM estimator is preferred to the first-differenced GMM estimator proposed by Arellano and Bond (1991) when variables are persistent and instruments for first differences are weak. Furthermore, the use of the two-step system GMM estimator is recommended (compared to the difference GMM estimator) when the panel dataset is unbalanced (which is the case in the present study) (e.g., Roodman, 2009).

The appropriateness of the two-step system GMM estimator is assessed through three diagnostic tests. These include the Arellano-Bond test of first-order serial correlation in the error term $(\mathrm{AR}(1))$, the Arellano-Bond test of no second-order autocorrelation in the error term (denoted AR(2)), and the Sargan/Hansen test of over-identifying restrictions (OID), the latter being useful in evaluating the validity of the instruments used in the regressions. Furthermore, it is recommended that the number of countries used in the analysis be higher than the number of instruments in the regressions so as to ensure that the above-mentioned diagnostic tests would not lose power (e.g., Bowsher, 2002; Roodman, 2009). The regressions based on the two-step system GMM technique have used 3 lags of the dependent variable as instruments and 3 lags of the 
endogenous variables as instruments, where the variables "INTERNET", "GRVOL", 2ODAVOL" and "RENT" have been considered as endogenous.

The empirical analysis based on the two-step system GMM-based (where the variable "TAXINST" is measured by the instability of non-resource tax revenue) has been conducted as follows. We present in column [1] of Table 2, the outcomes of the estimation of model (1), as it stands. Column [2] of the same Table reports the estimates arising from the estimation of a specification of model (1) that allows investigating how the effect of the Internet penetration on tax revenue instability varies for different values of the real per capita income. The model specification estimated is the dynamic model (1) in which we have introduced the interaction between the real per capita income variable, and the variable "INTERNET". Countries with higher real per capita income are likely to be in a better position to cope with tax revenue instability than relatively less advanced countries. Therefore, if the Internet penetration is negatively associated with tax revenue instability (notably through its effect on international trade), then we could expect it to exert a higher negative effect on tax revenue instability as countries' real per capita income rises.

In column [3] of Table 2, we display the estimates arising from the estimation of another variant of model (1) that allows examining whether the effect of the Internet on tax revenue instability depends on countries' level of participation in international trade, that is, how the effect of the Internet on tax revenue instability evolves for varying degrees of countries' participation in international trade. In the empirical literature, one commonly used indicator of countries' participation in international trade is the ratio of the sum of the country's exports and imports of goods and services to its GDP. However, this measure does not genuinely reflect the full degree of the country's integration into the world trade market: a country may enjoy a higher ratio of the sum of the country's exports and imports of goods and services to its GDP without experiencing a genuine greater integration into the world trade market. Therefore, we use the indicator proposed by Squalli and and Wilson (2011), which combines both countries' share of exports and imports in GDP, and their degree of integration into the world trade market. In other words, our indicator of participation in international trade (denoted "TRADE") is for a given country, the sum of exports and imports of goods and services to its GDP, adjusted by the proportion of the country's trade level relative to the average world trade (see Squalli and Wilson, 2011: p1758). To explore empirically whether (and if so how) the effect of the Internet penetration on tax revenue instability passes through countries' level of participation in international trade, we estimate another variant of model (1) in which we include both the variable "TRADE" and its interaction with the variable "INTERNET". Note that we have applied the natural logarithm to the variable "TRADE" in order 
to reduce its high skewness. These two variables have been considered as endogenous in the regression. The endogeneity (notably reverse causality) of the variable "TRADE" arises from the fact that countries that face a high degree of tax revenue instability due, among others, to their greater exposure to shocks (because of their increasing level of participation in international trade) may be willing to adopt measures that restrict their participation in international trade in order to stabilize their tax revenue.

As noted above, we also undertake a robustness check analysis of previous findings, using the two-step system GMM technique and the variable "TAXINST" is measured by the instability of total tax revenue. Table 3 contains the outcomes of the estimation of different specifications of the dynamic model (1) where the variable "TAXINST" is measured by the instability of total tax revenue. The first regression entails the estimation of model (1) as it stands (see results in column [1] of Table 3). The second regression involves estimating a version of model (1) that contains the interaction between the variables measuring respectively the Internet penetration and the real per capita income. The outcomes of this regression are reported in column [2] of Table 3, and help explore how the effect of the Internet on tax revenue instability varies across countries in the full sample. The third estimation involves checking whether the effect of the Internet on tax revenue instability translates through the international trade channel. To that effect, we estimate another specification of model (1) that includes the variable "TRADE" (in Logs) along with its interaction with the variable "INTERNET".

\section{Analysis of empirical outcomes}

Starting with the estimates presented in Table 1, we observe across the three columns that the coefficient of the variable "INTERNET" is always negative and significant at the $1 \%$ level, although the magnitude of the estimate varies across the columns. Taken in absolute value, the coefficient of this variable appears to be the highest for the EC2SLS-based regression and the lowest for the FE-based regression. A 1-point increase in the Internet penetration rate leads to: a $0.662(=0.00662 * 100)$ percent fall in the indicator of non-resource tax revenue instability (for the result based on the FE approach); a 0.945 (=0.00945*100) percent decrease in the indicator of non-resource tax revenue instability (for the result based on the FGLS approach); and a 1.17(= $0.0117 * 100$ ) percent decline in the indicator of non-resource tax revenue instability (for the result based on the EC2SLS technique). It is worth noting for the regression based on the EC2SLS approach that the p-value of the Sargan test of overidentification of the instruments amounts to 0.11, which is higher than 0.10: this validates the reliability of the estimates (in particular that of 
the variable "INTERNET") based on this estimator. On another note, the Between $\mathrm{R}^{2}$ from the EC2SLS-based regression is far higher than the Within $\mathrm{R}^{2}$ : this reflects the dominance of the between-country variations of variables over the within-country variations of variables ${ }^{6}$, and justifies the preference of the EC2SLS approach over the fixed effects 2SLS technique. Across the three columns, control variables (except for the variable "TERMSVOL") show similar sign and are significant at least at the 5\% level. Specifically, it appears - as expected - that development aid volatility, a higher dependence on natural resources, and inflation volatility are positively and significantly associated with non-resource tax revenue instability. However, the instability of terms of trade enhances non-resource tax revenue instability (at the 1\% level) only for results based on FE and FGLS estimators. For the EC2SLS-based regression, there is no significant effect (at the $10 \%$ level) of terms of trade instability on tax revenue instability. Incidentally, across the three columns of Table 1, economic growth volatility and real per capita income do not affect significantly (at the conventional levels) non-resource tax revenue instability.

Turning now to estimates presented in Tables 2 and 3, we note that the conditions for the consistency of the two-step system GMM estimator are met (see the bottom of all columns of the Tables). As expected, the p-values of the $\mathrm{AR}(1)$ and $\mathrm{AR}(2)$ tests are respectively lower than 0.01 (i.e., the $10 \%$ level of statistical significance), and higher than 0.01 ; the p-value of the OID test is always higher than 0.01 ; the number of countries also always exceeds the number of instruments used in the regressions; and finally, the coefficient of the one-period lag of the dependent variable is always positive and significant at the $1 \%$ level, thereby indicating the relevance of considering the dynamic model (1) in the analysis.

Taking up now the estimates in Table 2, we find in column [1] that the coefficient of "INTERNET" (which amounts to 0.0044) is negative (as in Table 1) and significant at the 5\% level. However, the magnitude of this coefficient is lower (in absolute value) than that the coefficients of the same variable in Table 1. Specifically, it is far lower (in absolute value) than the estimate of "INTERNET" arising from the regression based on the EC2SLS approach. This might be because the regression based on the EC2SLS technique has not account for the one-period lag of the dependent variable. Additionally, the regression based on the EC2SLS approach has not dealt with the potential endogeneity concern of many regressors in the same way as the regression based on the two-step system GMM estimator. Overall, the outcome based on our preferred estimator, i.e., the two-step system GMM approach suggests that a 1-point increase in the Internet penetration rate is associated with a $0.44(=0.0044 * 100)$ percent fall in the degree of non-resource

${ }^{6}$ See also the Within $\mathrm{R}^{2}$ of the FE-based regression which is small and of the same magnitude as the one of the EC2SLS-based regression. 
tax revenue instability. The results of control variables in column [1] of Table 2 indicate, in line with our theoretical expectations, that at least at the 5\% level, instability in non-resource tax revenue is positively driven by a rise in the real per capita income, higher economic growth volatility, a rise in the volatility of development aid, an increase in the dependence on natural resources, and higher inflation volatility. However, there is no significant effect (at the conventional levels) of terms of trade instability on non-resource tax revenue instability. Similar findings concerning control variables are also observed in the two other columns of Table 2. At the same time, according to estimates in column[2] of Table 2 , the interaction term of the variable ["INTERNET*Log(GDPC)"] is negative and significant at the $1 \%$ level, while the coefficient of "INTERNET" is yet positive, but significant only at the $10 \%$ level. Hence, taken jointly, these two outcomes suggest that at the 5\% level, the Internet exerts a higher negative effect on non-resource tax revenue instability, and the magnitude of this negative effect rises as countries experience a higher real per capita income. Put differently, less advanced countries have a lower non-resource tax revenue instability effect of the Internet than relatively advanced countries do. This finding aligns with our theoretical expectation. Results in column [3] suggest a negative and significant coefficient (at the 1\% level) of the variable "INTERNET", and also a negative and significant (at the $5 \%$ level) interaction term of the variable ["INTERNET*Log(TRADE)"]. Based on these two outcomes, we conclude that the effect of the Internet on non-resource tax revenue instability is always negative (irrespective of the degree of countries' participation in international trade). Additionally, the magnitude of this negative effect rises with the degree of countries' participation in international trade. These signify that the effect of the Internet on non-resource tax revenue instability genuinely translates through the international trade channel and, countries that enhance their participation in international trade enjoy a lower instability of non-resource tax revenue thanks to a rise in the Internet penetration rate. All in all, the hypothesis 2 set out in Section 2 appears to dominate the other two hypotheses, as far as the effect of the Internet on non-resource tax revenue instability through the international trade channel is concerned.

Results in Table 3 are consistent with those in Table 2. In column [1] of Table 3, we observe a negative and significant coefficient (at the 1\% level) of "INTERNET", which confirms the previous findings that the Internet use helps to reduce tax revenue instability, and notably here the instability of total tax revenue. In terms of the magnitude of the impact, a 1-point increase in the Internet penetration rate is associated with a $1.06\left(=0.0106^{*} 100\right)$ percent decline in the instability of total tax revenue. For control variables in column [1] of Table 3, it appears that the real per capita income and the terms of trade volatility do not influence significantly the instability of total tax revenue. However, the latter is positively and significantly (at least at the $5 \%$ level) driven by 
higher economic growth volatility, higher development aid volatility, a rise in the dependence on natural resources, and greater inflation volatility. Estimates in column [2] of Table 3 show a negative and significant (at the 5\% level) coefficient of the variable ["INTERNET*Log(GDPC)"], and a positive and significant (at the 1\% level) coefficient of "INTERNET". We conclude from these two results that the total effect of the Internet on the instability of total tax revenue changes sign (i.e., in particular, it becomes negative) and decreases above a certain level of real per capita income, which amounts to US\$1098.9 [= exponential (0.0341/0.00487)]. Thus, countries whose real per capita income is lower than US\$1098.9 experience a positive effect of the Internet on the instability of total tax revenue, and for this group of countries, the lower the real per capita income, the greater is the positive effect of the Internet on the instability of total tax revenue. This signifies that for poor countries (which are part of this group of countries), the Internet induces a rise in the instability of total tax revenue, finding which can be explained by the limited (both human and institutional - for example tax and customs administrations) capacity of these countries to cope with factors underpinning the instability of total tax revenue, even in the context of an increasing use of the Internet. For countries with a real per capita income higher than US\$1098.9, the Internet always exerts a negative effect on the instability of total tax revenue, and the magnitude of this negative effect rises as the real per capita income increases.

Results in column [3] of Table 3 indicate that the coefficients of both "INTERNET" and ["INTERNET*Log(TRADE)"] are negative and significant at the $1 \%$ level. Taken jointly, these two outcomes suggest that regardless of countries' level of participation in international trade, the Internet always leads to a lower instability of total tax revenue. Furthermore, the magnitude of this negative effect of the Internet on the instability of total tax revenue rises as countries enhance their participation in international trade. Overall, once again, the effect of the Internet on the instability of total tax revenue genuinely translates through the international trade channel, and countries that enhance their participation in international trade enjoy a higher negative effect of the Internet use on the instability of total tax revenue.

Estimates of control variables in columns [2] and [3] of Table 3 are largely consistent with those in column [1] of the same Table.

\section{Conclusion}

Using a sample of 142 countries over the period 1995-2017, this paper has investigated the effect of the Internet on tax revenue instability, notably through the international trade channel. The findings indicate that the Internet exerts a negative and significant effect on tax revenue 
instability (regardless of whether the latter is measured by non-resource tax revenue instability or by the instability of total tax revenue). Interestingly, the empirical outcomes suggest that this negative effect of the Internet on tax revenue instability passes through the international trade channel: regardless of countries' level of participation in international trade, the magnitude of the negative effect of the Internet on tax revenue instability rises as countries strengthen their participation in international trade.

There are potential benefits (but also challenges) associated with the Internet adoption in the current world of increasing digitization of economies (see for example OECD, 2016). Among those benefits highlighted in the recent literature are the strengthening of countries' participation in international trade, the enhancement of their tax revenue performance, and the enhancement of tax reform, including in developing countries. The present study adds to the very few existing studies on the effect of the Internet on public finances (including on tax revenue and the extent of tax reform) by showing that the Internet can also contribute to stabilizing tax revenue in countries that strengthen their participation in international trade. 


\section{References}

Abeliansky, A. L., and Hilbert, M. (2017). Digital technology and international trade: Is it the quantity of subscriptions or the quality of data speed that matters? Telecommunications Policy, 41(1), 35-48.

Acemoglu, D., Johnson, S., Robinson, J., and Thaicharoen, Y. (2003). Institutional causes, macroeconomic symptoms: Volatility, crises and growth. Journal of Monetary Economics, 50(1), $49-123$.

Acemoglu, K. D., and Zilibotti, F. (1997). Was Prometheus Unbound by Chance? Risk, Diversification, and Growth. Journal of Political Economy, 105(4), 709-751.

Acs, Z. J., Audretsch, D. B., and Feldman, M. P. (1994). R\&D spillovers and recipient firm size. The Review of Economics and Statistics, 76(2), 336-40.

Aguiar, M., and Gopinath, G. (2007). Emerging Markets Business Cycles: The Cycle is the Trend. Journal of Political Economy, 115(1), 11-69.

Ahmed, A.D., and Suardi, S. (2009). Macroeconomic Volatility, Trade and Financial Liberalization in Africa. World Development, 37(10), 1623-1636.

Álvarez, R., García-Marín, A., Ilabaca, S. (2018). Commodity price shocks and poverty reduction in Chile. Resources Policy, See online at: https://doi.org/10.1016/j.resourpol.2018.04.004

Arellano, M., and Bond, S. (1991). Some Tests of Specification for Panel Data: Monte Carlo Evidence and an Application to Employment Equations. Review of Economic Studies, 58, $277-$ 297.

Arthur, W. B. (2007). The structure of invention. Research Policy, 36(2), 274-287.

Baldwin, R. (1988). Hysteresis in Import Prices: The Beachhead Effect. American Economic Review, 78(4), 773-785.

Baltagi, B. H. (1981). Simultaneous equations with error components. Journal of Econometrics, 17 (2), 189-200.

Baltagi, B. H., and. Liu, L (2009). A Note on the Application of EC2SLS and EC3SLS Estimators, In Panel Data Models. Center for Policy Research Working Papers 116, Center for Policy Research, Maxwell School, Syracuse University, United States.

Bankolea, F. O., Osei, B., and Brown, K. M. (2015). The impact of information and communications technology infrastructure and complementary factors on Intra-African trade, Information Technology for Development, 21(1), 12-18.

Barrot, L.D., Calderón, C., and Servén, L. (2018). Openness, specialization, and the external vulnerability of developing countries. Journal of Development Economics, 134, 310-328.

Barthélémy, S., Binet, M-E., and Pentecôte, J-S. (2020). Worldwide economic recoveries from financial crises through the decades. Journal of International Money and Finance, 105, Article 102204. 
Behar, A., and Venables, A. (2011). Transport Costs and International Trade' in André de Palma, Robin Lindsey, Emile Quinet and Roger Vickerman (eds), Handbook of Transport Economics, Cheltenham, UK and Northampton, MA, USA: Edward Elgar Publishing, pp. 97-115.

Belderbos, R., and Sleuwaegen, L. (1998). Tariff Jumping FDI and Export Substitution: Japanese Electronics Firms in Europe. International Journal of Industrial Organization, 16(5), 601-638.

Benlagha, N., and Hemrit, W. (2020). Internet use and insurance growth: evidence from a panel of OECD countries. Technology in Society, 62, Article 101289.

Bleaney, M., Gemmell, N., and Greenaway, D. (1995). Tax revenue instability, with particular reference to Sub-Saharan Africa. Journal of Development Studies, 31, 883-902.

Blundell, R., and Bond, S. (1998). Initial Conditions and Moment Restrictions in Dynamic Panel Data Models. Journal of Econometrics, 87, 115-143.

Bowsher, C.G. (2002). On testing overidentifying restrictions in dynamic panel data models. Economics Letters 77(2), 211-220.

Brun J.-F., Chambas G., Guerineau S. (2011). Aide et Mobilisation Fiscale dans les pays en Développement, Jumbo, 21, 1-53.

Brun J.F., Chambas, G., and Mansour, M. (2015). "Tax Effort of Developing Countries: An Alternative Measure", In: Financing Sustainable Development Addressing Vulnerabilities, Chapter 11. Edited by Boussichas, M., and Guillaumont, P., Economica. FERDI.

Calderon, C., Loayza, N., and Schmidt-Hebbel, K. (2005). Does openness imply greater exposure? The World Bank Policy Research Working Paper Series 3733, Washington, DC.

Cariolle, J., Goujon, M., and Guillaumont, P. (2016). Has Structural Economic Vulnerability Decreased in Least Developed Countries? Lessons Drawn from Retrospective Indices. The Journal of Development Studies, 52(5), 591-606.

Cavallo, E. A., and Frankel, J. A. (2008). Does openness to trade make countries more vulnerable to sudden stops, or less? Using gravity to establish causality. Journal of International Money and Finance, 27(8), 1430-1452.

Chauvet, L., and Guillaumont, P. (2009). Aid, Volatility, and Growth Again: When Aid Volatility Matters and When it Does Not? Review of Development Economics, 13(3), 452-463.

Choi, C. (2003). Does Internet stimulate foreign direct investment? Journal of Policy Modeling, 25 (4), 319-326.

Choi, C (2010). The effect of the internet on service trade. Economics Letters, 109, 102-104.

Choi, C., and Yi, M.H. (2009). The effect of the Internet on economic growth: Evidence from cross-country panel data. Economics Letters, 105(1), 39-41.

Clarke, G. R. G. (2008). Has the internet increased exports for firms from low and middle-income countries? Information Economics and Policy, 20(1), 16-37. 
Clarke, G.R.G., and Wallsten, S.J. (2006). Has the internet increased trade? Developed and developing country evidence. Economic Inquiry, 44(3), 465-484.

Dabla-Norris, E., and Gündüz, Y. B. (2014). Exogenous Shocks and Growth Crises in LowIncome Countries: A Vulnerability Index. World Development, 59, 360-378.

Dawkins, C., and Whalley, J. (1997). Tax Structure and Revenue Instability Under External Shocks: Some General Equilibrium: Calculations for Côte d'Ivoire. Review of Development Economics, 1(1), 23-33.

Dercon, S. (2001). Assessing vulnerability to poverty. Oxford: Mimeo, Jesus College and CSAE, Department of Economics, Oxford University.

di Giovanni, J., and Levchenko, A. A. (2009). Trade openness and volatility. Review of Economics and Statistics, 91(3), 558-585.

Ding, Y. (2020). Impact of Internet on International-Trade from the Perspective of Information Asymmetry. In: Xu Z., Parizi R., Hammoudeh M., Loyola-González O. (eds) Cyber Security Intelligence and Analytics. CSIA 2020. Advances in Intelligent Systems and Computing, vol 1147. Springer, Cham

Ebeke, C., and Ehrhart, H. (2012). Tax Revenue Instability in Sub-Saharan Africa: Consequences and Remedies. Journal of African Economies, 21(1), 1-27.

Ebeke, C.H. (2014). Do International Remittances affect the level and the volatility of government tax revenue? Journal of International Development, 26(7), 1039-1053.

ECLAC (2016). The new digital revolution: From the consumer Internet to the industrial Internet. Economic Commission for Latin America and the Caribbean (ECLAC) - United Nations, CEPAL LC/L.4029(CMSI.5/4)/REV. 1 -LC/L.4029(CMSI.5/4.

Elbahnasawy, N. G. (2014). E-Government, Internet Adoption, and Corruption: An Empirical Investigation. World Development, 57, 114-126.

Elgin, C. (2013). Internet usage and the shadow economy: evidence from panel data. Economic System. 37, 111-121.

Essers, D. (2013). Developing country vulnerability in light of the global financial crisis: Shock therapy? Review of Development Finance, 3(2), 61-83.

Fink, C., Mattoo, A., and Neagu, I. C. (2005). Assessing the impact of communication costs on international trade. Journal of International Economics, 67(2), 428-445.

Forman, C., Goldfarb, A., and Greenstein, S. (2002). Digital Dispersion: An Industrial and Geographic Census of Commercial Internet Use. National Bureau of Economic Research, Cambridge, MA.

Freund, C. (2000). Different Paths to Free Trade: The Gains from Regionalism. Quarterly Journal of Economics, 115(4), 1317-1341. 
Freund, C., and Weinhold, D. (2002). The Internet and international trade in services. American Economic Review, 92, 236-240.

Freund, C., and Weinhold, D. (2004) The effect of the Internet on international trade. Journal of International Economics, 62(1), 171-189.

Gervais, A., and Jensen, J. B. (2019). The tradability of services: Geographic concentration and trade costs. Journal of International Economics, 118, 331-350.

Gnangnon, S.K. (2019). Does Aid for Information and Communications Technology Help Reduce the Global Digital Divide? Policy \& Internet, 11(3), 344-369.

Gnangnon, S.K. (2020a). Internet and tax reform in developing countries. Information Economics and Policy, 51, Article 100850.

Gnangnon, S.K. (2020b). General Budget Support and Tax Revenue Instability in Developing Countries. International Economic Journal, Published in June 2020. Access online at: https://doi.org/10.1080/10168737.2020.1780291

Gnangnon, S.K., and Brun, J-F (2018). Impact of Bridging the Internet Access Divide on Public Revenue Mobilization. Information Economics and Policy, 43, 23-33.

Gnangnon, S.K., and Brun, J-F (2019a). Internet and the structure of public revenue: resource revenue versus non-resource revenue. Journal of Economic Structures, 8, Article number: 1.

Gnangnon, S.K., and Brun, J-F. (2019b). Tax Reform and Public Revenue Instability in Developing Countries: Does the Volatility of Development Aid Matter? Journal of International Development, 31(8), 764-785.

Gnangnon. S.K., and Iyer, H. (2018). Does bridging the Internet Access Divide contribute to enhancing countries' integration into the global trade in services markets? Telecommunications Policy, 42(1), 61-77.

Guillaumont, P. (2009). An economic vulnerability index: its design and use for international development policy. Oxford Development Studies, 37(3), 193-228.

Haddad, M., Lim J. J., Munro L., Saborowski C., and Shepherd B. (2011). Volatility, Export, Diversification, and Policy", Chapter 11, In Managing Openness: Trade and Outward-Oriented Growth after the Crisis. World Bank, Washington, D.C.

Haddad, M., Lim, J. J., Pancaro, C., and Saborowski, C. (2013). Trade openness reduces growth volatility when countries are well diversified. Canadian Journal of Economics 46(2), 765-790.

Hjort, J., and Poulsen, J. (2019). The Arrival of Fast Internet and Employment in Africa. American Economic Review, 109(3), 1032-79.

Hummels, D. (2007). Transportation Costs and International Trade in the Second Era of Globalization. Journal of Economic Perspectives, 21(3), 131-154. 
Jensen, R. (2007). The Digital Provide: Information (Technology), Market Performance, and Welfare in the South Indian Fisheries Sector. The Quarterly Journal of Economics, 122, 879-924.

Joya, O. (2015). Growth and volatility in resource-rich countries: Does diversification help? Structural Change and Economic Dynamics, 35, 38-55.

Kanyam, D.A., Kostandini, G., and Ferreira, S. (2017). The Mobile Phone Revolution: Have Mobile Phones and the Internet Reduced Corruption in Sub-Saharan Africa? World Development, 99, 271-284.

Kenny, C. (2003). The Internet and economic growth in less-developed countries: a case of managing expectations? Oxford Development Studies, 31(1), 99-113.

Kim, D-H., Lin, S-C., and Suen, Y-B. (2016). Trade, growth and growth volatility: New panel evidence. International Review of Economics \& Finance, 45, 384-399.

Ko, K.W. (2007). Internet externalities and location of foreign direct investment: A comparison between developed and developing countries. Information Economics and Policy, 19(1), 1-23.

Koren, M., and Tenreyro, S. (2007). Volatility and development. Quarterly Journal of Economics, 122(1), 243-287.

Kose, M. A., and Yi, K. M. (2006). Can the standard international business cycle model explain the relation between trade and co-movement? Journal of International Economics, 68, 267-295.

Lapatinas, A. (2019). The effect of the Internet on economic sophistication: An empirical analysis Economics Letters, 174, 35-38.

Lashitew, A.A., Ross, M.L., and Werker, E. (2020). What Drives Successful Economic Diversification in Resource-Rich Countries?, The World Bank Research Observer, lkaa001, https://doi.org/10.1093/wbro/lkaa001

Lim, D. (1983). Instability of Government Revenue and Expenditure in Less Developed Countries. World Development, 11(5), 447-50.

Limão, N., and Venables, A. J. (2001). Infrastructure, geographical disadvantage, and transport costs. World Bank Economic Review, 15(3), 451-479.

Lin, F. (2015). Estimating the effect of the Internet on international trade. The Journal of International Trade \& Economic Development, 24(3), 409-428.

Lio, M., Liu, M., and Ou, Y. (2011). Can the internet reduce corruption? A cross country study based on dynamic panel data models. Government Information Quarterly, 28, 47-53.

Malik, A., and Temple, J. (2009). The geography of output volatility. Journal of Development Economics, 90(2), 163-178.

Maurseth, P.B. (2018). The effect of the Internet on economic growth: Counter-evidence from cross-country panel data. Economics Letters, 172, 74-77. 
McGregor, T. (2017). Commodity price shocks, growth and structural transformation in lowincome countries. The Quarterly Review of Economics and Finance, 65, 285-303.

Meijers, H. (2006). Diffusion of the Internet and low inflation in the information economy. Information Economics and Policy, 18(1), 1-23.

Melitz, M. (2003). The Impact of Trade on Intra-industry Reallocations and Aggregate Industry Productivity. Econometrica, 71(6), 1695-1725.

Montalbano, P. (2011). Trade Openness and Developing Countries' Vulnerability: Concepts, Misconceptions, and Directions for Research. World Development, 39(9), 1489-1502.

Morrissey, O. (2015). Aid and Government Fiscal Behavior: Assessing Recent Evidence. World Development, 69, 98-105.

Najarzadeh, R., Rahimzadeh, F., and Reed, M. (2014). Does the Internet increase labor productivity? Evidence from a cross-country dynamic panel. Journal of Policy Modeling, 36, 986993.

Narayan, P.K. and Lu, R. (2011). Are shocks to commodity prices persistent? Applied Energy, 88(1), 409-416.

Nicholson, J. and Noonan, R. (2014). Digital Economy and Cross-Border Trade: The value of digitally deliverable services. ESA Issue Brief \#01-14, US Department of Commerce: Economics and Statistics Administration.

OECD (2015). Innovation Policies for Inclusive Growth, OECD Publishing, Paris.

OECD (2016) Economic and Social Benefits of Internet Openness. Background Report for the 2016 Ministerial Meeting on the Digital Economy. OECD Digital Economy Papers, No. 257, OECD, Paris.

Osnago, A., and Tan, S.W. (2016). Disaggregating the Impact of the Internet on International Trade. The World Bank Policy Research Working Paper N WPS7785, World Bank, Washington, D.C.

Ozkan, F.G., and Unsal, D.F. (2012). Global Financial Crisis, Financial Contagion and Emerging Markets. International Monetary Fund Working Paper, WP/12/293, Washington, D.C.

Paunov, C. (2013). Innovation and Inclusive Development: A Discussion of the Main Policy Issues. OECD Science, Technology and Industry Working Paper No. 2013/1, OECD Publishing.

Paunov, C., and Rollo, V. (2016). Has the Internet Fostered Inclusive Innovation in the Developing World? World Development, 78(C), 587-609.

Petropoulou, D. (2011). Information costs, networks and intermediation in international trade. Globalization Institute Working Papers 76, Federal Reserve Bank of Dallas.

Raddatz, C. (2007). Are external shocks responsible for the instability of output in low-income countries?. Journal of Development Economics, 84(1), 155-187. 
Rauch, J. (1996). Trade and Search: Social Capital, Sogo Shosha, and Spillovers. NBER Working Paper No. 5618. Cambridge: National Bureau of Economic Research.

Rauch, J.E., and Casella, A. (2003). Overcoming Informational Barriers to International Resource Allocation: Prices and Ties. The Economic Journal, 113 (484), 21-42.

Rauch, J.E., and Trindade, V. (2002). Ethnic Chinese Networks in International Trade. The Review of Economics and Statistics, 84(1), 116-130.

Razin, A., Sadka, E., and Coury, T. (2003). Trade openness, investment instability and terms-oftrade volatility. Journal of International Economics, 61, 285-306.

Roberts, M., and Tybout, J. (1997). The Decision to Export in Columbia: An Empirical Model of Entry with Sunk Costs. American Economic Review, 87(4), 545-564.

Rodrik, D. (1999). Where did all the growth go? External shocks, social conflict, and growth collapses. Journal of Economic Growth, 4(4), 385-412.

Roodman, D. (2006). How to do xtabond2: An introduction to difference and system GMM in stata. Center for Global Development, Working Paper, (103).

Roodman, D. M. (2009). A note on the theme of too many instruments, Oxford Bulletin of Economic and Statistics, 71(1), 135-158.

Salahuddin, M., Alam, K., and Ozturk, I. (2016). The effects of Internet usage and economic growth on CO2 emissions in OECD countries: A panel investigation. Renewable and Sustainable Energy Reviews, 62, 1226-1235.

Salahuddin, M., and Alam, K. (2015). Internet usage, electricity consumption and economic growth in Australia: A time series evidence. Telematics and Informatics, 32(4), 862-878.

Salahuddin, M., and Gow, J. (2016). The effects of Internet usage, financial development and trade openness on economic growth in South Africa: A time series analysis. Telematics and Informatics, 33(4), 1141-1154.

Solimano, A., and Calderón, D. (2017). The copper sector, fiscal rules, and stabilization funds in Chile. UNU-WIDER Working Paper, 2017/53, Helsinki.

Squalli, J., and Wilson, K. (2011). A New Measure of Trade Openness. The World Economy, 34(10), 1745-1770.

Tang, L. H. (2006). Communication costs and trade of differentiated goods, Review of International Economics, 14(1), 54-68.

Tay, C. (2015). The Impact of the Internet on trade in education. Technological and Economic Development of Economy, 21(6), 833-854.

Vemuri, V.K., and Siddiqi, S. (2009). Impact of commercialization of the internet on international trade: A panel study using the extended gravity model. The International Trade Journal, 23(4), 458-484. 
Visser, R. (2019). The effect of the internet on the margins of trade. Information Economics and Policy, 46, 41-54.

von Arnim, R., Tröster, B., Staritz, C., and Raza, W. (2018). Commodity price shocks and the distribution of income in commodity-dependent least developed countries. Journal of Policy Modeling, 40(2), 434-451

von Haldenwang, C., Morrisey, O., Ivanyna, M., Bordon, I., and von Schiller, A. (2013). Study on the vulnerability and resilience factors of tax revenues in developing countries. Study commissioned by the European Commission.

Yartey, C.A. (2008). Financial development, the structure of capital markets, and the global digital divide. Information Economics and Policy, 20(2), 208-227.

Yi, M.H., and Choi, C. (2005). The effect of the Internet on inflation: Panel data evidence. Journal of Policy Modeling, 27(7), 885-889. 


\section{FIGURES}

Figure 1: Scatter plot between the Internet penetration and tax revenue instability_over the full sample
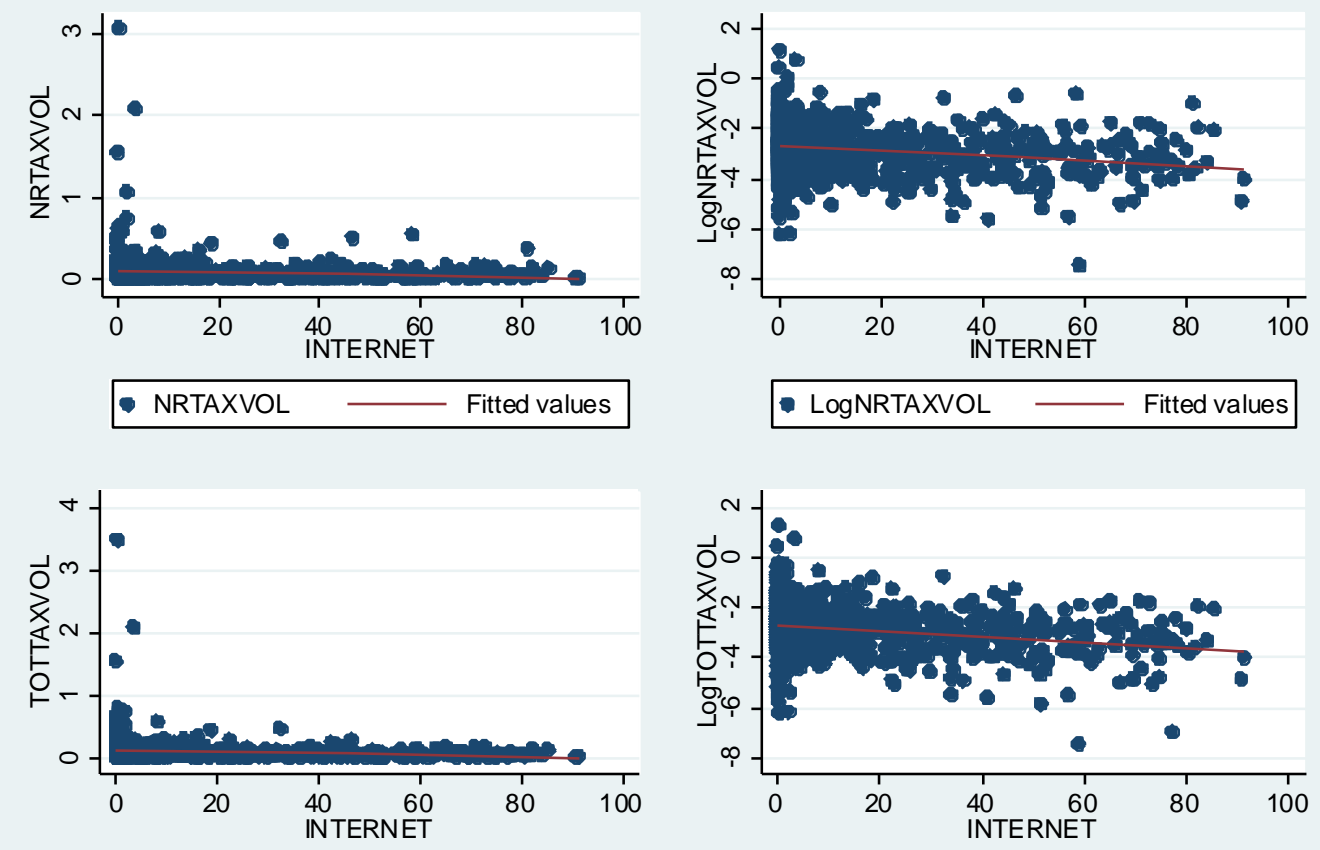

- TOTTAXVOL — Fitted values

- LogTOTTAXVOL Fitted values

Source: Author 


\section{TABLES and APPENDICES}

Table 1: Effect of the Internet penetration on non-resource tax revenue instability

Estimators: FE, FGLS and EC2SLS

\begin{tabular}{|c|c|c|c|}
\hline & FE & $\begin{array}{l}\text { FGLS (with panel-specific } \\
\text { first order Autocorrelation) }\end{array}$ & EC2SLS \\
\hline \multirow[t]{2}{*}{ Variables } & Log(NRTAXVOL) & Log(NRTAXVOL) & Log(NRTAXVOL) \\
\hline & $(1)$ & $(2)$ & (3) \\
\hline \multirow[t]{2}{*}{ INTERNET $_{\mathrm{t}-1}$} & $-0.00662 * * *$ & $-0.00945^{* * *}$ & $-0.0117 * * *$ \\
\hline & $(0.00148)$ & $(0.000971)$ & $(0.00418)$ \\
\hline \multirow[t]{2}{*}{$\log (\mathrm{GDPC})$} & -0.0262 & -0.00994 & 0.0373 \\
\hline & $(0.155)$ & $(0.0123)$ & $(0.0518)$ \\
\hline \multirow[t]{2}{*}{$\log (\text { GRVOL })_{t-1}$} & -0.0450 & -0.00702 & -0.0263 \\
\hline & $(0.0351)$ & $(0.0165)$ & $(0.0322)$ \\
\hline \multirow[t]{2}{*}{$\log (\text { ODAVOL })_{t-1}$} & $0.0225^{* * *}$ & $0.0548^{* * *}$ & $0.0577 * *$ \\
\hline & $(0.00795)$ & $(0.0108)$ & $(0.0282)$ \\
\hline \multirow[t]{2}{*}{$\mathrm{RENT}_{\mathrm{t}-1}$} & $0.00579 * *$ & $0.0244 * * *$ & $0.0209 * * *$ \\
\hline & $(0.00290)$ & $(0.00130)$ & $(0.00373)$ \\
\hline \multirow[t]{2}{*}{ Log(INFLVOL) } & $0.125^{* * *}$ & $0.140^{* * *}$ & $0.144 * * *$ \\
\hline & $(0.0134)$ & $(0.00597)$ & $(0.0319)$ \\
\hline \multirow[t]{2}{*}{ Log(TERMSVOL) } & $0.0711 * * *$ & $0.0232 * * *$ & 0.0270 \\
\hline & $(0.0164)$ & $(0.00899)$ & $(0.0382)$ \\
\hline \multirow[t]{2}{*}{ Constant } & $-2.509 * *$ & $-2.880 * * *$ & $-3.103^{* * *}$ \\
\hline & $(1.184)$ & $(0.112)$ & $(0.394)$ \\
\hline Observations - Countries & $677-142$ & $673-138$ & $642-141$ \\
\hline Within $\mathrm{R}^{2}$ & 0.0496 & & 0.0508 \\
\hline Between $\mathrm{R}^{2}$ & & & 0.4130 \\
\hline Overall $\mathrm{R}^{2}$ & & & 0.1969 \\
\hline Pseudo R-squared & & 0.4601 & \\
\hline $\begin{array}{l}\text { Robust Sargan-Hansen } \\
\text { (overidentifying restrictions } \\
\text { test) Statistic (P-value) }\end{array}$ & & & $14.530(0.11)$ \\
\hline
\end{tabular}

Note: ${ }^{*}$-value $<0.1$; **p-value $<0.05$; ***p-value $<0.01$. Robust standard errors are in parenthesis. The Pseudo $\mathrm{R}^{2}$ has been calculated for the regression based on the FGLS estimator, as the correlation coefficient between the dependent variable and its predicted values. In the EC2SLS regressions, the variable "INTERNET" (and not its one-period lag as in columns [1] and [2]) has been considered as endogenous, and instrumented by the variables "SHURBPOP" and "SHPOPELEC". 
Table 2: Effect of the Internet penetration on non-resource tax revenue instability for varying levels of real per capita income/participation in international trade

Estimator: Two-Step System GMM

\begin{tabular}{|c|c|c|c|}
\hline Variables & Log(NRTAXVOL) & Log(NRTAXVOL) & Log(NRTAXVOL) \\
\hline & $(1)$ & $(2)$ & (3) \\
\hline \multirow[t]{2}{*}{$\log (\text { NRTAXVOL })_{\mathrm{t}-1}$} & $0.0802 * * *$ & $0.0886^{* * *}$ & $0.0798^{* * *}$ \\
\hline & $(0.0247)$ & $(0.0234)$ & $(0.0203)$ \\
\hline \multirow[t]{2}{*}{ INTERNET } & $-0.00442^{* *}$ & $0.0210^{*}$ & $-0.0194 * * *$ \\
\hline & $(0.00200)$ & $(0.0109)$ & $(0.00696)$ \\
\hline \multirow[t]{2}{*}{ INTERNET*Log(GDPC) } & & $-0.00307 * *$ & \\
\hline & & $(0.00128)$ & \\
\hline \multirow[t]{2}{*}{ INTERNET*Log(TRADE) } & & & $-0.00194 * *$ \\
\hline & & & $(0.000842)$ \\
\hline \multirow{2}{*}{ Log(TRADE) } & & & $0.0530^{*}$ \\
\hline & & & $(0.0282)$ \\
\hline \multirow[t]{2}{*}{$\log ($ GDPC $)$} & $-0.115^{* *}$ & $-0.0743^{*}$ & $-0.125^{* * *}$ \\
\hline & $(0.0452)$ & $(0.0404)$ & $(0.0318)$ \\
\hline \multirow[t]{2}{*}{$\log ($ GRVOL $)$} & $0.126 * *$ & $0.140 * * *$ & $0.196 * * *$ \\
\hline & $(0.0491)$ & $(0.0391)$ & $(0.0266)$ \\
\hline \multirow[t]{2}{*}{ Log(ODAVOL) } & $0.156^{* * *}$ & $0.173 * * *$ & $0.121 * * *$ \\
\hline & $(0.0367)$ & $(0.0241)$ & $(0.0172)$ \\
\hline \multirow[t]{2}{*}{ RENT } & $0.0272^{* * *}$ & $0.0246 * * *$ & $0.0257 * * *$ \\
\hline & $(0.00267)$ & $(0.00222)$ & $(0.00221)$ \\
\hline \multirow[t]{2}{*}{ Log(INFLVOL) } & $0.105^{* * *}$ & $0.0936 * * *$ & $0.0762 * * *$ \\
\hline & $(0.0263)$ & $(0.0254)$ & $(0.0187)$ \\
\hline \multirow[t]{2}{*}{ Log(TERMSVOL) } & 0.0517 & 0.0371 & 0.0234 \\
\hline & $(0.0327)$ & $(0.0273)$ & $(0.0200)$ \\
\hline \multirow[t]{2}{*}{ Constant } & $-1.712^{* * *}$ & $-1.999 * * *$ & $-1.344 * * *$ \\
\hline & $(0.321)$ & $(0.313)$ & $(0.470)$ \\
\hline Observations - Countries & $646-142$ & $646-142$ & $621-138$ \\
\hline Number of Instruments & 77 & 88 & 105 \\
\hline AR1 (P-Value) & 0.0000 & 0.0000 & 0.0000 \\
\hline AR2 (P-Value) & 0.6707 & 0.6523 & 0.3809 \\
\hline OID (P-Value) & 0.7527 & 0.9314 & 0.5673 \\
\hline
\end{tabular}

Note: ${ }^{*}$-value $<0.1 ;{ }^{* *}$-value $<0.05 ;{ }^{* *} p$-value $<0.01$. Robust standard errors are in parenthesis. In the twostep system GMM estimations, the variables INTERNET, TRADE, GRVOL, ODAVOL and RENT have been considered as endogenous. The other variables have been considered as exogenous. The GMM regressions have used 3 lags of the dependent variable as instruments and 3 lags of the endogenous variables as instruments. Time dummies have been included in these regressions. 
Table 3: Effect of the Internet penetration on the instability of total tax revenue Estimator: Two-Step System GMM

\begin{tabular}{|c|c|c|c|}
\hline Variables & Log(TOTTAXVOL) & Log(TOT'TAXVOL) & Log(TOTTAXVOL) \\
\hline & $(1)$ & $(2)$ & (3) \\
\hline \multirow[t]{2}{*}{$\log (\text { TOTTAXVOL) })_{t-1}$} & $0.0928 * * *$ & $0.0978^{* * *}$ & $0.0631 * * *$ \\
\hline & $(0.0305)$ & $(0.0341)$ & $(0.0215)$ \\
\hline \multirow{2}{*}{ INTERNET } & $-0.0106^{* * *}$ & $0.0341 * *$ & $-0.0248 * * *$ \\
\hline & $(0.00345)$ & $(0.0174)$ & $(0.00543)$ \\
\hline \multirow[t]{2}{*}{ INTERNET*Log(GDPC) } & & $-0.00487 * *$ & \\
\hline & & $(0.00203)$ & \\
\hline \multirow[t]{2}{*}{ INTERNET*Log(TRADE) } & & & $-0.00215^{* * *}$ \\
\hline & & & $(0.000577)$ \\
\hline \multirow[t]{2}{*}{ Log(TRADE) } & & & $0.0629 * * *$ \\
\hline & & & $(0.0243)$ \\
\hline \multirow[t]{2}{*}{$\log ($ GDPC $)$} & -0.0715 & -0.0473 & $-0.113^{* * *}$ \\
\hline & $(0.0564)$ & $(0.0449)$ & $(0.0365)$ \\
\hline \multirow[t]{2}{*}{ Log(GRVOL) } & $0.191^{* * *}$ & $0.173^{* * *}$ & $0.259 * * *$ \\
\hline & $(0.0512)$ & $(0.0484)$ & $(0.0299)$ \\
\hline \multirow[t]{2}{*}{ Log(ODAVOL) } & $0.0849 * *$ & $0.103^{* * *}$ & $0.0700 * * *$ \\
\hline & $(0.0389)$ & $(0.0353)$ & $(0.0242)$ \\
\hline \multirow[t]{2}{*}{ RENT } & $0.0212 * * *$ & $0.0210^{* * *}$ & $0.0258^{* * *}$ \\
\hline & $(0.00351)$ & $(0.00340)$ & $(0.00269)$ \\
\hline \multirow[t]{2}{*}{ Log(INFLVOL) } & $0.127 * * *$ & $0.114^{* * *}$ & $0.0633 * * *$ \\
\hline & $(0.0307)$ & $(0.0329)$ & $(0.0229)$ \\
\hline \multirow[t]{2}{*}{ Log(TERMSVOL) } & -0.0163 & $0.0593^{*}$ & -0.0132 \\
\hline & $(0.0337)$ & $(0.0309)$ & $(0.0261)$ \\
\hline \multirow[t]{2}{*}{ Constant } & $-2.043 * * *$ & $-2.168^{* * *}$ & $-1.524 * * *$ \\
\hline & $(0.407)$ & $(0.385)$ & $(0.468)$ \\
\hline Observations - Countries & $654-140$ & $654-140$ & $623-136$ \\
\hline Number of Instruments & 82 & 75 & 107 \\
\hline AR1 (P-Value) & 0.0000 & 0.0000 & 0.0000 \\
\hline AR2 (P-Value) & 0.4167 & 0.4393 & 0.1841 \\
\hline OID (P-Value) & 0.7544 & 0.7764 & 0.6507 \\
\hline
\end{tabular}

Note: ${ }^{*} p$-value $<0.1 ;{ }^{* *} p$-value $<0.05 ;{ }^{* * *} p$-value $<0.01$. Robust standard errors are in parenthesis. In the twostep system GMM estimations, the variables "INTERNET", "TRADE", "GRVOL", "ODAVOL" and "RENT" have been considered as endogenous. The other variables have been considered as exogenous. The GMM regressions have used 3 lags of the dependent variable as instruments and 3 lags of the endogenous variables as instruments. Time dummies have been included in these regressions. 
Appendix 1: Definition and Source of variables

\begin{tabular}{|c|c|c|}
\hline Variable & Definition & Source \\
\hline NRTAXVOL & $\begin{array}{c}\text { This is the measure of the instability of non-resource tax revenue (excluding } \\
\text { social contributions). Non-resource tax revenue is the difference between total } \\
\text { tax revenue (\% GDP) (excluding social contributions) and tax revenue collected } \\
\text { on natural resources (the latter include a significant component of economic } \\
\text { rent, primarily from oil and mining activities). } \\
\text { The instability of non-resource tax revenue has been calculated as the standard } \\
\text { deviation of annual growth rate of non-resource tax revenue (\% GDP) over } \\
\text { non-overlapping sub-periods of 3-year data. }\end{array}$ & $\begin{array}{l}\text { Author's calculation based on data from the } \\
\text { UNU-WIDER database. UNU-WIDER Public } \\
\text { Revenue Dataset could be found online at: } \\
\text { https://www.wider.unu.edu/project/governmen } \\
\underline{\text { t-revenue-dataset }}\end{array}$ \\
\hline TOTTAXVOL & $\begin{array}{c}\text { This is the measure of the instability of total tax revenue instability. Total tax } \\
\text { revenue }(\% \text { GDP) (excluding social contributions) represents the difference } \\
\text { between total public revenue ( } \% \text { GDP) (excluding grants, and excluding social } \\
\text { contributions) and non-tax revenue (\% GDP). It has been calculated as the } \\
\text { standard deviation of annual growth rate of tax revenue }(\% \text { GDP) over non- } \\
\text { overlapping sub-periods of } 3 \text {-year data. }\end{array}$ & $\begin{array}{l}\text { Author's calculation based on data from the } \\
\text { UNU-WIDER database. UNU-WIDER Public } \\
\text { Revenue Dataset could be found online at: } \\
\text { https://www.wider.unu.edu/project/governmen } \\
\underline{\text { t-revenue-dataset }}\end{array}$ \\
\hline INTERNET & $\begin{array}{l}\text { This is the indicator of the Internet penetration. It measures the number } \\
\text { of individuals using the Internet, in percentage of the population. }\end{array}$ & World Development Indicators (WDI) \\
\hline GRVOL & $\begin{array}{l}\text { This is the measure of the volatility of economic growth rate. It has been } \\
\text { calculated as the standard deviation of annual economic growth rate (growth } \\
\text { rate of real GDP) over non-overlapping sub-periods of 3-year. }\end{array}$ & $\begin{array}{l}\text { Author's calculation based on economic growth } \\
\text { rate data extracted from the WDI of the World } \\
\text { Bank. }\end{array}$ \\
\hline TERMSVOL & $\begin{array}{l}\text { This is the measure of terms of trade volatility. Terms of trade represent the } \\
\text { ratio of the export price index to import price index. Terms of trade volatility } \\
\text { has been calculated as the standard deviation of annual terms of trade growth } \\
\text { over 3-year non-overlapping sub-periods. }\end{array}$ & $\begin{array}{l}\text { Author's calculation based on terms of trade } \\
\text { data extracted from the WDI. }\end{array}$ \\
\hline INFLVOL & $\begin{array}{l}\text { Inflation volatility is calculated as the standard deviation of inflation rate over } \\
\text { non-overlapping sub-periods of 3-year. }\end{array}$ & $\begin{array}{l}\text { Author's calculation based on inflation data } \\
\text { extracted from the WDI }\end{array}$ \\
\hline ODAVOL & $\begin{array}{c}\text { Inflation volatility is calculated as the standard deviation of the growth rate of } \\
\text { development aid (in real values, i.e., US Dollar, 2017, Constant Prices) rate over } \\
\text { non-overlapping sub-periods of 3-year. }\end{array}$ & $\begin{array}{l}\text { Author's calculation based on inflation data } \\
\text { extracted from the OECD }\end{array}$ \\
\hline TRADE & $\begin{array}{l}\text { This is the indicator of a country's participation in international trade. It is } \\
\text { basically the measure of trade openness suggested by Squalli and Wilson (2011). }\end{array}$ & $\begin{array}{c}\text { Author's calculation based on data extracted } \\
\text { from the WDI }\end{array}$ \\
\hline
\end{tabular}


Appendix 2: Descriptive statistics on variables used in the model

\begin{tabular}{|c|c|c|c|c|c|}
\hline Variable & Observations & Mean & Standard deviation & Minimum & Maximum \\
\hline NRTAXVOL & 646 & 0.084 & 0.130 & 0.002 & 2.074 \\
\hline TOTTAXVOL & 629 & 0.084 & 0.129 & 0.001 & 2.074 \\
\hline INTERNET & 646 & 15.537 & 17.635 & 0.000 & 77.300 \\
\hline TRADE & 621 & 0.002 & 0.007 & 0.000 & 0.072 \\
\hline GDPC & 646 & 4389.685 & 5125.296 & 192.174 & 37373.860 \\
\hline INFLVOL & 646 & 3.504 & 6.981 & 0.101 & 116.751 \\
\hline TERMSVOL & 646 & 0.104 & 0.084 & 0.000 & 0.596 \\
\hline GRVOL & 646 & 2.645 & 4.531 & 0.007 & 96.049 \\
\hline ODAVOL & 646 & 1.701 & 22.024 & 0.000 & 554.265 \\
\hline RENT & 646 & 8.531 & 11.508 & 0.000 & 66.097 \\
\hline SHURBPOP & 646 & 47.687 & 21.441 & 8.037 & 100.000 \\
\hline SHPOPELEC & 611 & 68.456 & 33.467 & 2.048 & 100.000 \\
\hline
\end{tabular}

Appendix 3: List of countries contained in the full Sample

\begin{tabular}{|c|c|c|c|c|c|}
\hline \multicolumn{6}{|c|}{ Full sample } \\
\hline Albania & Chile & Guatemala & $\begin{array}{l}\text { Macao SAR, } \\
\text { China }\end{array}$ & $\begin{array}{l}\text { Papua New } \\
\text { Guinea }\end{array}$ & Togo \\
\hline Algeria & China & Guinea & Madagascar & Paraguay & Tonga \\
\hline Angola & Colombia & Guinea-Bissau & Malawi & Peru & Trinidad and Tobago \\
\hline $\begin{array}{c}\text { Antigua and } \\
\text { Barbuda }\end{array}$ & Comoros & Guyana & Malaysia & Philippines & Tunisia \\
\hline Argentina & $\begin{array}{l}\text { Congo, Dem. } \\
\text { Rep. }\end{array}$ & Haiti & Maldives & Rwanda & Turkey \\
\hline Armenia & Congo, Rep. & Honduras & Malta & Samoa & Turkmenistan \\
\hline Aruba & Costa Rica & $\begin{array}{c}\text { Hong Kong SAR, } \\
\text { China }\end{array}$ & Marshall Islands & $\begin{array}{l}\text { Sao Tome and } \\
\text { Principe }\end{array}$ & Uganda \\
\hline Azerbaijan & Cote d'Ivoire & India & Mauritania & Saudi Arabia & Ukraine \\
\hline Bahamas, The & Croatia & Indonesia & Mauritius & Senegal & Uruguay \\
\hline Bangladesh & Cuba & Iran, Islamic Rep. & Mexico & Serbia & Uzbekistan \\
\hline Barbados & Cyprus & Iraq & $\begin{array}{l}\text { Micronesia, Fed. } \\
\text { Sts. }\end{array}$ & Seychelles & Vanuatu \\
\hline Belarus & Dominica & Israel & Moldova & Sierra Leone & Venezuela, RB \\
\hline Belize & $\begin{array}{l}\text { Dominican } \\
\text { Republic }\end{array}$ & Jamaica & Mongolia & Singapore & Vietnam \\
\hline Benin & Ecuador & Jordan & Morocco & Slovenia & West Bank and Gaza \\
\hline Bhutan & Egypt, Arab Rep. & Kazakhstan & Mozambique & Solomon Islands & Yemen, Rep. \\
\hline Bolivia & El Salvador & Kenya & Myanmar & South Africa & Zambia \\
\hline $\begin{array}{l}\text { Bosnia and } \\
\text { Herzegovina }\end{array}$ & Equatorial Guinea & Kiribati & Namibia & Sri Lanka & Zimbabwe \\
\hline Botswana & Eritrea & Korea, Rep. & Nepal & $\begin{array}{l}\text { St. Kitts and } \\
\text { Nevis }\end{array}$ & \\
\hline Brazil & Eswatini & Kuwait & Nicaragua & St. Lucia & \\
\hline $\begin{array}{c}\text { Brunei } \\
\text { Darussalam }\end{array}$ & Ethiopia & Kyrgyz Republic & Niger & $\begin{array}{l}\text { St. Vincent and } \\
\text { the Grenadines }\end{array}$ & \\
\hline Burkina Faso & Fiji & Lao PDR & Nigeria & Sudan & \\
\hline Burundi & Gabon & Lebanon & North Macedonia & Suriname & \\
\hline Cambodia & Gambia, The & Lesotho & Pakistan & Tajikistan & \\
\hline $\begin{array}{c}\text { Central African } \\
\text { Republic } \\
\end{array}$ & Georgia & Liberia & Palau & Tanzania & \\
\hline Chad & Grenada & Libya & Panama & Thailand & \\
\hline
\end{tabular}

